\title{
Farmer's Perception on Economics and Varietal Performance of High Yielding Multicut Napier Fodder - DHN-6: Result of Front Line Demonstration in Ramanagar District, Karnataka, India
}

\author{
S. Kamala Bai ${ }^{*}$, K. H. Nagaraj ${ }^{2}$, Syed Mazhar Ali ${ }^{3}$, S. C. Ranganath ${ }^{4}$ and B. T. Rayudu \\ ${ }^{1}$ Department of Agronomy, ICAR, University of Agricultural Sciences, GKVK, \\ Bengaluru-560065, Karnataka, India \\ ${ }^{2}$ Department of Extension, ICAR, University of Agricultural Sciences, GKVK, \\ Bengaluru-560065, Karnataka, India \\ ${ }^{3}$ Department of Agril Engineering, ICAR, University of Agricultural Sciences, GKVK, \\ Bengaluru-560065, Karnataka, India \\ ${ }^{4}$ ATARI, ICAR, University of Agricultural Sciences, GKVK, Bengaluru-560065, \\ Karnataka, India \\ *Corresponding author
}

\section{A B S T R A C T}

Livestock is an integral component of rainfed farming system. Livestock rearing is also integrated with crop farming to provide security against crop failure due to uncertain monsoon conditions. Estimates reveal that livestock contribute $40 \%$ of total annual

Keywords

Farmer's Perception, Economics and Varietal Demonstration,

Karnataka

Article Info

Accepted:

18 May 2018

Available Online: Performance, Front Line

10 June 2018 income of a farmer. In this situation, feeding livestock is need based in rainfed farming situation. Major constrains that prevail in livestock rearing is deficit of availability of green fodder throughout the year and lack of awareness about high yielding improved fodder varieties. With this background, to mitigate the fodder shortage in the district of Ramanagara, improved new high yielding variety viz., DHN-6 was introduced. The results highlighted that farmers had appreciated the performance of improved fodder variety for its high yielding green fodder (242t/ha/year) and its high palatability (98\%). The adoption trend and interest of farmers was analyzed by estimating the quantity of improved slips produced by Front Line Demonstrated (FLD) beneficiaries, which showed that both FLD participated and non- participated farmers were content with the performance of DHN-6 variety due to its high palatability and easiness to harvest due to absence of pubescence. The data related to selling of new fodder variety slips by KVK and the farmers themselves within the district and outside the district has not only generated income Rs.1, 06,500 and Rs. 4, 27,500 respectively, but highlighted the spread of new variety and increase in average milk yield of $0.25 \mathrm{lt} /$ day

\section{Introduction}

Ramanagara District is one among the 30 districts of Karnataka state. It is predominantly a dry farming district which lies in geographic position of North latitude between $12^{\circ} 33^{\prime}$ to a $12^{\circ} 58^{\prime}$ and East latitude $77^{\circ} 13^{\prime}$ to $77^{\circ} 25^{\prime}$. The district comprises four 
taluks viz., Ramanagara, Magadi, Chanapatna and Kanakapura with 18 hoblis. This district is categorized under Zone-5 of Agro- Climatic zones of Karnataka. The temperature prevailing is $14^{\circ} \mathrm{C}$ (Minimum) and $31^{\circ} \mathrm{C}$ (Maximum). The highest day temperature range between $31^{\circ} \mathrm{C}$ to $40^{\circ} \mathrm{C}$. The district receives annual rainfall of $854 \mathrm{~mm}$.

The district has a gross cropped area of 1.69 lakh ha (47.69\% of the total geographical area) out of which net sown area is 1.64 lakh ha. (Anon, 2013-14) with 2.60 lakhs household. The total number of agriculture farm families in the district is 2.71 lakh among which small and marginal farm families constitute 2.50 lakh (92.34\%). Agriculture is the main economy of the district. Other allied agricultural activities followed are livestock and sericulture. The total population of the livestock in the district is 6.95 Lakhs, which comprises cattle, buffalo, sheep and goat (Table $1 \&$ Fig.1))

According to the survey and the report of the Planning Commission Khanna, 1989 the availability of the green fodder and dry fodder in Southern Plateau and hills region constituting Andhra Pradesh, Tamil Nadu and Karnataka states is below $40 \%$.

Krishi Vigyan Kendra, Ramanagara initially conducted base line survey to study the existing situation of the livestock rearing and the green fodder availability. During the survey period 2012-13 the availability of average green fodder in lean period was 10864 metric tons that was unfeasible to meet the requirement of green fodder for the cattle. The main source of the feed for the cattle is green fodder obtained from fodder maize or local napier grass and cereal based straw. The major constrain in livestock rearing in the district is primarily non- availability of the green fodder throughout the year, non- accessibility of the palatable and non pubescence fodder crop that yield more per unit area. Thus resulting in poor health of animal and low milk yield. This in turn influenced the economic security of the farmers.

The survey also revealed that the main source of the green fodder for the cattle is from annual fodder maize crop and multicut napier grass which are grown in small areas under monsoon. Fodder maize is annual crop which yields 60 tons/ha /year under single cut, while Napier grass though, it is multicut its yield potential is low 120 tons/ha/year when compared to the new high yielding napier grasses that are realized. Though scarcity is green fodder exists in the district there is ample opportunities to increase the green fodder availability as the district is blessed with congenial climatic condition of the livestock rearing, lot of scope and potential for increasing the supply of balanced quality green fodder in the district.

With this background, Krishi Vigyan Kendra implemented various Capacity building, extension programme and technological backstopping programmes to increase the green fodder production in the district.

Among multicut fodder crops, although many varieties have been released for cultivation, their adoption by farmers is minimal. In vast areas where these fodder crops are grown, situation are differing from the area prevailing as the research station is encountered. As a result, improved varieties found superior well in research stations may not perform up to the expectation in farmer's field (Baidu- Forson, 1997, Sthapit et al., 1996). This situation has lead farmers not showing preference to new varieties leading to negligible coverage by them in framers field. Hence, farmers continue to cultivate local varieties having lower genetic potential therefore the fodder productivity is low. Keeping this in view, a study was planned by providing fodder 
varieties acceptable to farmers through participatory varietal selection. This gives closer farmer involvement from the initial stage of varietal evaluation and selection and help in identification of better varieties suitable for a given situation.

\section{Materials and Methods}

Initially On- farm Testing (OFT) on "Performance of Multicut Fodder in Ramanagar district" was taken up in Magadi Taluk with an objective to assess the performance and the attributes of multicut fodder varieties as well as to understand the needs and preference of farmers on fodder varietal choice. Based on the farmers requirement to guage the comparative performance, from the basket of the varieties available, three multicut fodder varieties namely Co-3, COFS-29 and DHN-6 along with local were tested in farmers field. After planting fodder slips regular visits of the scientists during the growth period and subsequent harvest period was made to keep up the continuous interaction with the farmer. This enabled proper execution of the trials as well as in the gatherings farmers perception on the testing material.

The farmers themselves judged the performance of the fodder varieties in each trial visually as well as quantitatively so that the farmers themselves solely made the final judgment and ranking of varieties. During the study observations on quantity parameters (measurable) viz., Plant height $(\mathrm{cm})$, leaf length $(\mathrm{cm})$, leaf width $(\mathrm{cm})$, Number of leaves/culm, Stem Girth $(\mathrm{cm})$, Green fodder yield (t/ha/yr) and Palatability was recorded.

\section{Results and Discussion}

Results indicated that DHN-6 multicut Napier fodder recorded highest yield (220t/ha/yr) followed by COFS-29 (160t/ha/yr) and CO-3 (160t/ha/yr) compared to locally grown NB-21 (120t/ha/yr). Highest palatability (93\%) was recorded in COFS-29 followed by DHN-6 (92\%) (Table $2 \&$ Fig.2). Considering some of the important qualitative parameters on growth (visually), pubescence and preference revealed that the variety DHN-6 came very near to the farmers requirement as it was most acceptable for its luxurious growth, high palatability, no pubescence, and availability of green fodder throughout the year and its effect on health and yield of the milk Table 3. The farmers were satisfied with the performance of these varieties and were keen to plant more in the ensuring season (Kamala Bai, 2017).

Based on the outcome of the OFT results, front line demonstrations (FLD) on "Demonstration of High Yielding Multicut Napier Fodder-DHN-6" in comparison with locally grown multicut fodder were taken up in the farmers field in Ramanagara and Chanapatna taluk of the district. Twenty-one demonstrations were taken up in two FLD programmes. Meanwhile, Parallel dissemination of the knowledge about DHN-6 fodder and Field day conducted by the KVK encouraged an NGO at Kanakapura for planning FLDs in the farmers field. Planned intervention from preparation of planting materials through stem cuttings and root slips followed by method of planting the slips were demonstrated in farmer's field. Periodic field visit and implementation various extension programme by the scientists of KVK (Table 5) followed by the group discussion with the farmers about the new variety DHN-6 was taken up. The result of three consecutive years (2013-16) indicated that the farmers selected and accepted DHN-6 over their local variety as it was found superior for yield (242.8 $\mathrm{t} / \mathrm{ha} / \mathrm{yr}$ ). Local Napier was not preferred by the farmers due to low yield (176.25 t/ha/yr) and low palatability and presence of hairs that caused skin injury and reduced the efficiency of harvesting the fodder Table 4. 
In any fodder cultivation, stem cutting/ root slips is only source of seed material. With the continuous intervention by KVK on supplying fodder slips to conduct FLD and its outcome, there was huge demand for the DHN-6 fodder slips by the adjoining farmers of the district and neighbouring districts due to wellaccepted features of DHN-6 fodder variety.

The impact of any intervention in the technology is measured in terms of the benefits reaped by the farmers, improvement on socio economic condition and economic security.

The issues of the impact are delineated in many outcomes such as increase in milk yield and area under DHN-6 fodder and participatory seed production programme.
Increase in Milk yield and area under high yielding fodder DHN-6

The success of any demonstrations depends on the results of given technology. If a technology improves economic condition than the chances of adoption of such technology remains high or vice versa. The participatory and non-participatory farmers views were pooled about the new Napier fodder DHN-6. The farmers appreciated the introduction of new high yielding fodder napier DHN-6 variety for its high palatability and non pubescence quality attributes. Field day conducted during each year directly led to popularity of the variety by media and line departments, which resulted in increase in area to 31 hectares and increase in milk yield by 0.25 litre /day (Table 6).

Table.1 Livestock Population in Ramanagara District

\begin{tabular}{|c|l|c|}
\hline$\#$ & \multicolumn{1}{|c|}{ Details } & No \\
\hline 1 & Cattle & 266192 \\
\hline 2 & Buffalo & 40304 \\
\hline 3 & Goats & 166647 \\
\hline 4 & Sheep & 222035 \\
\hline & Total livestock population & 695178 \\
\hline
\end{tabular}

Source- Ramanagara District at Glance 2013

Table.2 Mean Performance of Multicut fodder varieties

\begin{tabular}{|c|c|c|c|c|c|c|c|}
\hline $\begin{array}{l}\text { Fodder } \\
\text { varieties }\end{array}$ & $\begin{array}{c}\text { Stem } \\
\text { height } \\
(\mathrm{cm})\end{array}$ & $\begin{array}{l}\text { No. of } \\
\text { tillers/ } \\
\text { culm }\end{array}$ & $\begin{array}{l}\text { Leaf } \\
\text { length } \\
(\mathrm{cm})\end{array}$ & $\begin{array}{l}\text { Leaf } \\
\text { width } \\
\text { (cm) }\end{array}$ & $\begin{array}{l}\text { No. of } \\
\text { leaves/ } \\
\text { culm }\end{array}$ & $\begin{array}{c}\text { Stem } \\
\text { diameter } \\
(\mathrm{cm})\end{array}$ & $\begin{array}{c}\text { Green } \\
\text { fodder yield } \\
(\text { t/ha/yr })\end{array}$ \\
\hline $\begin{array}{l}\text { T1- Local } \\
\text { Check }\end{array}$ & 204.4 & 23.0 & 112.6 & 4.2 & 135.6 & 5.8 & 85.8 \\
\hline T2- Co-3 & 217.5 & 22.8 & 123.0 & 4.1 & 163.6 & 5.6 & 120.2 \\
\hline T3-COFS-29 & 223.6 & 13.0 & 80.3 & 4.5 & 95.2 & 2.8 & 160.4 \\
\hline T4- DHN-6 & 249.8 & 25.0 & 96.5 & 5.3 & 190.5 & 7.2 & 220.6 \\
\hline SEm士 & 2.4 & 0.7 & 1.6 & 0.2 & 6.8 & 0.2 & 4.2 \\
\hline$C D(\mathrm{p}=0.05)$ & 7.4 & 2.2 & 5.00 & 0.6 & 21.1 & 0.6 & 13.1 \\
\hline
\end{tabular}


Table.3 Farmers perception on quality parameters and ranking of multicut fodder crops

\begin{tabular}{|l|c|c|c|c|c|}
\hline \multicolumn{1}{|c|}{ Parameters } & \multicolumn{4}{c|}{ Opinion } & DHN-6 \\
\hline Growth & Local Check & Co-3 & COFS-29 & Abundant green foliage \\
\hline Pubescence & Lush green & Luxuriant & Moderate & Abundar \\
\hline Palatability & More & Less & Absent & Absent \\
\hline Preference & Poor Palatable & Moderately & Moderately & Highly Palatable \\
\hline Effects on health of animal & Less preferred & Moderately & Moderately & Highly preferred \\
\hline Ranking of Fodder Varieties & Poor & Good & Good & Very good \\
\hline
\end{tabular}

Table.4 Mean growth and yield variation between improved variety and Local Check under Front Line Demonstrations at different locations

\begin{tabular}{|l|c|c|}
\hline \multicolumn{1}{|c|}{ Parameters } & Demo (DHN-6) & Local Napier - Check \\
\hline Stem height (cm) & 334.6 & 245.4 \\
\hline Stem diameter $(\mathrm{cm})$ & 6.25 & 5.3 \\
\hline No. of tillers/culm & 27.4 & 22.7 \\
\hline Av. No. of slips/stem & 7 & 6 \\
\hline Leaf length (cm & 110.45 & 100.75 \\
\hline Leaf width (cm) & 5.9 & 5.15 \\
\hline Green fodder yield (kg/culm) & 12.3 & 10.8 \\
\hline Palatability (\%) & 98.35 & 81.6 \\
\hline Cumulative Yield (t/ha/year) & 242.8 & 176.25 \\
\hline
\end{tabular}

Table.5 Extension activities conducted on upscaling of fodder crops

\begin{tabular}{|l|l|}
\multicolumn{1}{|c|}{ KVK Intervention } \\
\hline FLD \\
\hline OFT \\
\hline On-Campus training \\
\hline Off-Campus training \\
\hline Exposure Visits \\
\hline Field Visits \\
\hline Diagnostic Visits \\
\hline Field Days \\
\hline Guest Lectures \\
\hline Collaborative programs \\
\hline Method Demonstrations \\
\hline Group discussion \\
\hline TV Programs \\
\hline Publications \\
\hline Farmers visit to K VK \\
\hline Consultancy \\
\hline
\end{tabular}

\begin{tabular}{|c|c|c|c|c|c|c|}
\hline \multicolumn{6}{|c|}{ Year } & \multirow[t]{2}{*}{ Total } \\
\hline 2011-12 & 2012-13 & 2013-14 & 2014-15 & 2015-16 & 2016-17 & \\
\hline 1 & 1 & 1 & 1 & 1 & 1 & 6 \\
\hline- & - & 1 & 1 & 1 & 1 & 4 \\
\hline 1 & 1 & 4 & 4 & 4 & 2 & 16 \\
\hline- & 2 & 6 & 8 & 6 & 10 & 32 \\
\hline- & - & 1 & 1 & 1 & 1 & 4 \\
\hline 4 & 6 & 8 & 12 & 23 & 34 & 87 \\
\hline 1 & 2 & 2 & 3 & 4 & 6 & 18 \\
\hline 1 & 2 & 1 & 1 & 1 & - & 6 \\
\hline 5 & 6 & 8 & 12 & 16 & 8 & 55 \\
\hline 1 & - & 1 & 1 & 1 & 3 & 6 \\
\hline 2 & 4 & 2 & 2 & 7 & 8 & 25 \\
\hline - & - & 1 & 3 & 2 & 2 & 8 \\
\hline- & - & - & 1 & - & - & 1 \\
\hline 1 & 2 & 4 & 8 & 3 & 2 & 20 \\
\hline 22 & 30 & 18 & 32 & 28 & 33 & 163 \\
\hline 12 & 20 & 23 & 20 & 26 & 38 & 139 \\
\hline
\end{tabular}


Table.6 Production and impact on up scaling of fodder crops in Ramanagara District

\begin{tabular}{|l|c|}
\hline \multicolumn{1}{|c|}{ Particulars } & Numbers \\
\hline Capacity Building & 48 \\
\hline Farmers trained & 1344 \\
\hline Field days & 6 \\
\hline Farmers participated in field days & 186 \\
\hline No. Slips produced (KVK + Farmers) & 425000 \\
\hline No. of slips outsourced to other district & 35000 \\
\hline No. Farmers to whom slips were sold & 1820 \\
\hline No. of exposure visits conducted & 6 \\
\hline Area covered in dist (ha) & 32 \\
\hline Average increase in milk yield / day (lt) & $0.25-0.50$ \\
\hline Total Income generated by farmer (Rs. /year) & 30000 \\
\hline Total Income generated at K VK & 425000 \\
\hline
\end{tabular}
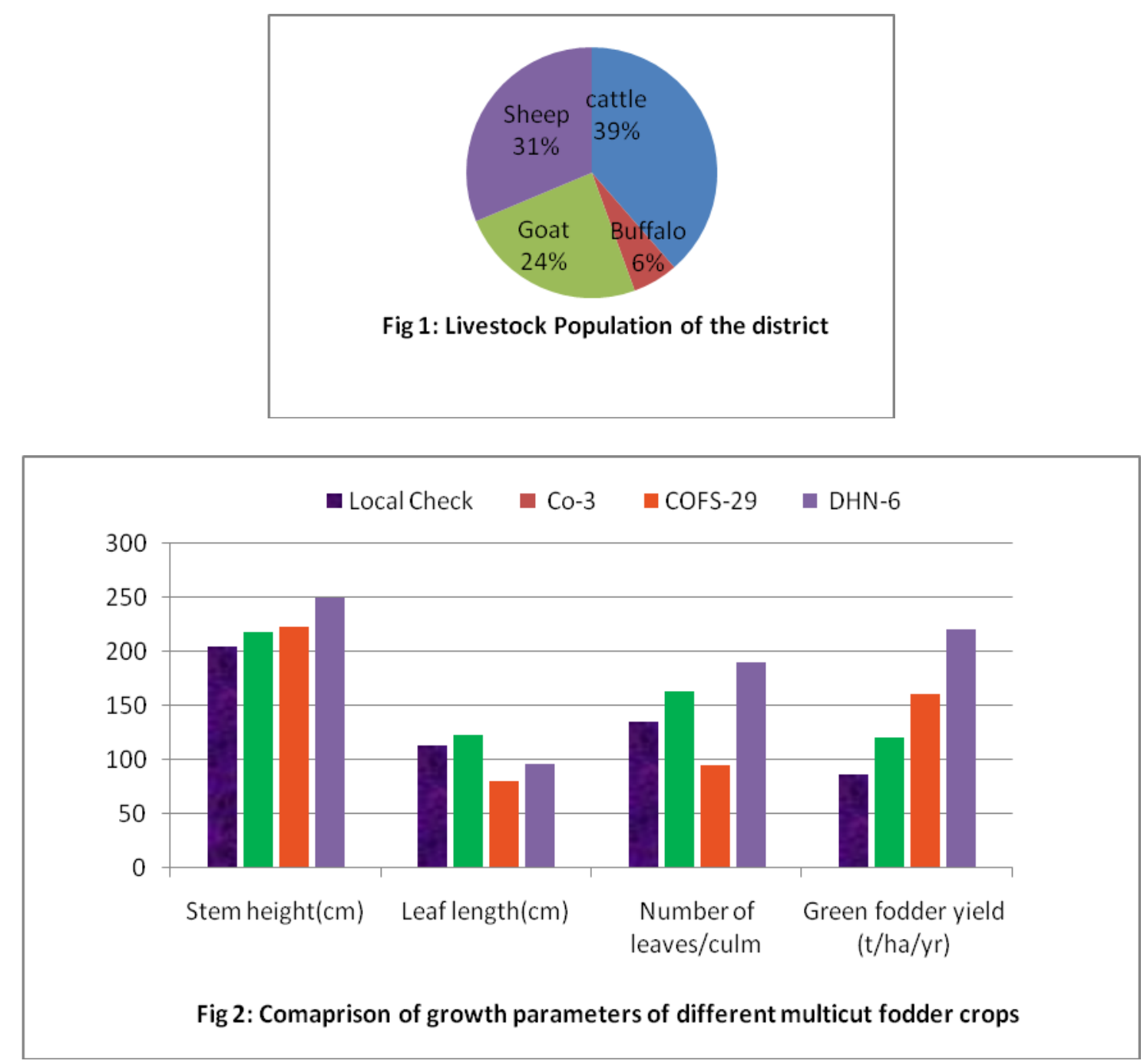


\section{Participatory Seed production:}

Initially KVK could supply DHN-6 fodder slips from fodder cafeteria to take up FLD to the participatory farmers within the district and outside the district namely Hassan, Bangalore rural, Tumkur and Chikbalapur. With time, on demand for the seed materials DHN-6, KVK identified interested FLD famers in each taluk to take up participatory seed production with an objective to supply stem/ root slips to both participatory and non participatory farmers who are in need and also to the farmers outside the district. This not only met the demand to meet the fodder slips but also curtailed the transportation charges to the farmers. Further, the farmer responsible for seed production supplied genuine seed material@ Rs.1/ per stem cuttings. This is added income to his lively hood.

As a success, one small farmer Mr. Devraj, from Ramangara taluk owning an area of 2 acres raised his status as progressive farmer in supplying DHN-6 fodder slips with the technical support of KVK coupled with his commitment and enthusiasm. In a span of two consecutive years he increased DHN-6 seed production area from 10 guntas to 30 guntas and supplied fodder slips varying from Rs/1to Rs. 2/- per slip earning an additional income of Rs.30, 000 per year (Table-6). From the inception of the seed production area during the year 2014 till 2016, Devraj has supplied around 1.5 lakh fodder slips to the need based farmers within and adjoining districts.

As a token of motivation and inspiration Mr. Devraj was honoured by KVK as Best Technocrat in fodder production and was felicitated by KVK on Kisan day during the year 2016 transferring for effectively implementing and transferring the technology to the needy farmers. Similarly the other farmers who have resorted to fodder seed production were of opinion that venturing into the activity has helped them to earn additional income

\section{Farmers' perception about fodder Intervention by KVK}

Extension programme such as OFT/ FLD, capacity building and various extension programme conducted by KVK (table 5) and large-scale demonstration by $\mathrm{NGO}$ proved well in dissemination of knowledge about new fodder variety. OFT/ FLD Participatory and non-participatory farmers revealed that in diary farming diet and health of animals plays an important role. For any livestock farming to be a profitable enterprise, availability of green fodder throughout the year supplemented with balanced diet is a key for good health and high milk production. In dairy, nearly $70 \%$ of expenditure is incurred on feed of the cattle. If this expenditure is reduced, it directly incurs less cost of production resulting in high returns. Apart from high yielding features, DHN-6 is coupled with ample quantity of proteins, fats, carbohydrates and minerals. High moisture content in the green fodder makes digestion easy. KVK conducted numerous capacity building programmes to educate farmers on feed and fodder management which not only resulted in replacing old variety with new high yielding variety and increase in milk yield by 0.25 lt/day.

The superior variety supplied green fodder throughout the year and increased the milk yield by $0.25 \mathrm{lt} / \mathrm{day}$. Thus improving socio economic security of the farmers in diary farming.

\section{References}

Anonymous, 1999, Economic Survey 199899, Government of Karnataka, Bangalore 
Anonymous, 2013, Ramanagara District at Glance, 2013-14, District Statistical officer, Ramanagara.

Baidu-Forson, 1997, On-station farmer participatory varietal evaluation: a strategy for client-oriented breeding. Experimental Agriculture, 33 (1). pp. 43-50. ISSN 0014-4797

Kamala Bai, S., K.H. Nagaraj, Syed Mazhar Ali, S.C. Ranganath and B.T. Rayudu, 2017, Performance and Dissemination of Multicut Fodder Crops in Ramanagara District, Karnataka State, India, Int.J.Curr.Microbiol.App.Sci (2017) 6(10): 4918-4923.

Sthapit. B.R., K.D., Jjoshi and J.R., Witcombe, 1996, Farmer Participatory Crop Improvement. iii: Participatory Plant Breeding, A Case Study for Rice in Nepal, in Experimental Agriculture. October 1996, 26-38

\section{How to cite this article:}

Kamala Bai S., K. H. Nagaraj, Syed Mazhar Ali, S. C. Ranganath and Rayudu B. T. 2018. Farmer's Perception on Economics and Varietal Performance of High Yielding Multicut Napier Fodder - DHN-6: Result of Front Line Demonstration in Ramanagar District, Karnataka, India. Int.J.Curr.Microbiol.App.Sci. 7(06): 1947-1954. doi: https://doi.org/10.20546/ijcmas.2018.706.231 